\title{
A structural functionalism point of view: Ritual cere- mony philosophy of Grebeg Maulud at Kasunanan palace, Surakarta
}

\author{
Joko Lulut Amboro ${ }^{1 *}$, Novita Wahyuningsih ${ }^{2}$, Nadia Sigi Prameswari ${ }^{3}$ \\ 1, 2 Universitas Sebelas Maret, Surakarta, Indonesia \\ ${ }^{3}$ Universitas Negeri Semarang, Semarang, Indonesia
}

\section{Keywords \\ Structural \\ Functionalism \\ Philosophy \\ Ritual \\ Grebeg maulud}

Received: 7 November 2019

Accepted: 16 January 2020

Published: 13 June 2020

\begin{abstract}
This study aims to reveal the philosophy of the ritual ceremony of Grebeg Maulud at Kasunanan Palace Surakarta from a functional point of view. This study used a qualitative approach. This study used a qualitative approach. The data is collected through observations, literature studies, interviews, and documentation with the society, who are the actors in the ritual. There are many studies on the Grebeg Maulud ritual ceremony. It focuses on the history and development of the ceremony; no study focuses on the relationship between the Grebeg ceremony and expressive symbols (art). This study is very important considering this ceremony is still around today, but most of the younger generation do not understand the expressive symbols in it. There is a correlation between the constituent symbols (religion) and the expressive symbol (art) in religious rituals. The constituent symbols in the Grebeg Maulud ritual are reflected in the Gunungan, which contains the philosophy of the nature of God and the relationship of humans with God to achieve the perfection of life known as the Paraning Dumadi - Manunggaling Kawula - Gusti. The expressive symbol in the Gunungan symbolizes the male and the female.
\end{abstract}

(C) 2020 The Author(s). Published by TAF Publishing

\section{INTRODUCTION}

Ritual is form ceremony or celebration that relates to some belief or religion characterized by special nature, which creates a sublime respect in the sense of a sacred experience (O'dea, 1995). Grebeg Maulud at Kasunanan Palace Surakarta is a form of ritual that has been implemented continuously in Java, Indonesia. This Ritual is one of the regular events each year at Kasunanan Palace located in Surakarta, Central Java, Indonesia. This event aims to commemorate the day of the Maulud Prophet Muhammad SAW. In this ceremony, there is a great Tumpeng of Gunungan from Surakarta Palace to Surakarta Mosque which is located near the North Square of Surakarta. Thousands of Surakarta and surrounding residents gather to seek blessings. Many of them come from the suburbs of Surakarta, such as: Sragen, Karanganyar, Wonogiri and other areas that are further away. Many foreign tourists also see the ritual. So did all the servants of Kasunanan Palace Surakarta gathered during the ritual ceremony of Grebeg Maulud was held. Traders flock to market all sorts of sales items. In addition to being a blessing for traders who make a living, Grebeg Maulud is also a solemn ritual that must be done.

Grebeg Maulud existed since the Kingdom era in Indonesia. At that time Raden Patah was crowned Sultan I Sultanate of Demak as the first Islamic kingdom in Java that had destroyed the Majapahit Empire in 1478 ad or 1400 Saka known as Candrasengkala Sirna lost Kertaning Earth. The Ritual of Grebeg Maulud with the apex of the Gunungan is the symbol of the king's charity to his people and bring blessings. People believe that the objects in the Gunungan have magical powers. Gunungan is comprised of Gunungan Lanang (Gunungan male) and Gunungan Wadon (Gunungan

* corresponding author: Joko Lulut Amboro

†email: jl.amboro030380@staff.uns.ac.id 
female). Gunungan is made of various kinds of traditional food, tall-shaped towering like a phallus depicting a man and another yoni-shaped woman depicting women (Poeger, 2002).

The awareness of religiousness or religious and community issues is not missed from the functionalist talks. Parsons (195), including functionalist adherents, that seen religious contributions to culture based on its significance, which is something that defines the experience (transedental reference); Something that is outside the empirical world (Galuh, 2019; O'dea, 1995). The phenomenon of religious consciousness in social reality is understood by the functional concept of the framework of structural functionalism theory. This theory sees that society as a social system consists of one part with each other and intertwined with each other in balance (equilibrium). Changes of one part will affect the overall system condition (Ritzer, 1996). In this case religions include rituals in them as one form of human behaviour that has been institutes, is part of the whole social system, and serves for the community especially for the integration. Based on the background above, there is a problem: How is the philosophy of the ritual ceremony of Grebeg Maulud at Kasunanan Palace Surakarta in a structural functionalism point of view?

\section{Purpose}

The purpose of this study is to reveal the philosophy of the ritual ceremony of Grebeg Maulud at Kasunanan Palace Surakarta in a functional point of view.

\section{Literature Gap}

There are studies on the Grebeg Maulud ritual ceremony, as a whole it focuses on the history (Adib \& Gustami, 2003) and development of the ceremony (Adib \& Gustami, 2003), there is no study that focuses on the relationship between the Grebeg ceremony and expressive symbols (art).

\section{Significance}

This study is very important considering the existence of this ceremony is still around today, but most of the younger generation do not understand the expressive symbols in it.

\section{LITERATURE REVIEW \\ Grebeg Maulud}

Grebeg is one of the ritual communications (Serena \& Richard, 2007) which is different from daily language. According to Fredy (2009) Grebeg is a traditional palace ceremony which is usually held to commemorate religious holyday. Grebeg is a Javanese cultural ritual related to the commemoration of Islamic holidays (Kuncoro, 2018). Grebeg
Maulud is a traditional ritual that has been known for a long time and has existed since the Majapahit era (Soepanto \& Bambang, 1991). Communication in rituals is something sacred because in its activities there are sacred ceremonies and people gather to hold the sacred ceremony (Berg, 2001). The purpose of a ritual is to create meaning (Adler \& George, 2006; Ngwaru, 2017).

Visual Gunungan Grebeg Maulud Kraton Surakarta functions as a manifestation of the king's generosity or a blessing from the king as well as a medium for the spread of Islam in Java (Adib \& Gustami, 2003). Some of the elements of Gunungan Grebeg Maulud include: Gunungan Lanang, Gunungan Wadon, Gunungan Anakan, Gunungan Ancak Cantoko, Canthang Balung (Adib \& Gustami, 2003). Previous research in understanding the function and existence of Grebeg Maulud in the Kraton Surakarta used an anthropological approach with structural theory (Koentjaraningrat, 1987). Utami (2011) states that Grebeg Maulud is used as a means of preaching. Grebeg Maulud as a traditional value that exists in society that still smells like Kejawen (Saddhono, 2009). From another point of view, Grebeg maulud has a meaning and representation of aesthetic values in Islam-Java (Purwadi, 2003).

The purpose of Grebeg Maulud is to commemorate the birthday of the Prophet Muhammad SAW and become a celebration that can entertain the public with the art of gamelan. The Grebeg Maulud celebration is organized by the Surakarta Palace and in collaboration with the Surakarta regional government. There are several activities at the celebration, including: (1) There are booths for exhibitions and sales of religious books and educational books; (2) There are stands of national heroes that can educate young people to respect heroes; (3) The existence of Islamic religious lectures and other activities that support the da'wah of Islam. Grebeg Maulud celebration is actually a celebration to increase Islam. The main activity of this celebration is the existence of Islamic da'wah which aims as an introduction and means of developing the Islamic religion, instilling strong religious character and mentality (Adib \& Gustami, 2003).

\section{Cultural as a System Symbolization}

Discussion of structural functionalism theory of Parsons begins with four important schemes regarding the function of all action systems, the scheme is known as AGIL scheme. Previously we had to know in advance what function is being discussed here, the function is a collection of activities aimed at the fulfillment of the needs of the system.

According to Parsons there are four essential functions that are absolutely necessary for all social systems, includ- 
ing systems of behavioral organisms fulfilling the need for customization (Adaptation), with the abbreviation $\mathrm{A}$, the personality system meets the needs of achievement Objectives (Goal Attainment), abbreviated G, social system is a source of integration (Integration), abbreviated I, and the cultural system maintains the existing patterns (Laten pattern-maintenance), abbreviated L (Ritzer, 1996; Silva \& Madushani, 2017).

The need for adaptation (adaptation) is fulfilled through the sub-systems of cognitive symbols (Cognitive symbolization) which form a noncritical knowledge of science or basic cognitive behavior. A very important function here the system should be able to adapt by tackling external situations, and the system should be able to adapt to the environment can also adjust the environment for its needs.

Goal attainment through an expressive symbol (expressive symbolization), the form of a noncritical of expressive deeds in the artwork and other symbolic communication. The goal-scoring is very important, where the system must be able to enter and achieve its main objectives.

Integration is fulfilled through several moral symbols (Moral symbolization), the form of the context of normative provisions in ethics, customs or association of associations. In addition, it organizes and manages all three functions (AGL).

Laten pattern-Maintenance is resolved through the symbol of the constituency (Constitutive symbolization) which forms the form of belief or basic and core religious behavior. A system must be able to regulate and keep the interrelationship of the parts into its components. A system must maintain and improve the motivation of individual and cultural patterns (Waters, 1994). Sub-systems These symbols are systems that are interconnected with each other, so it can be seen in the following schemes:

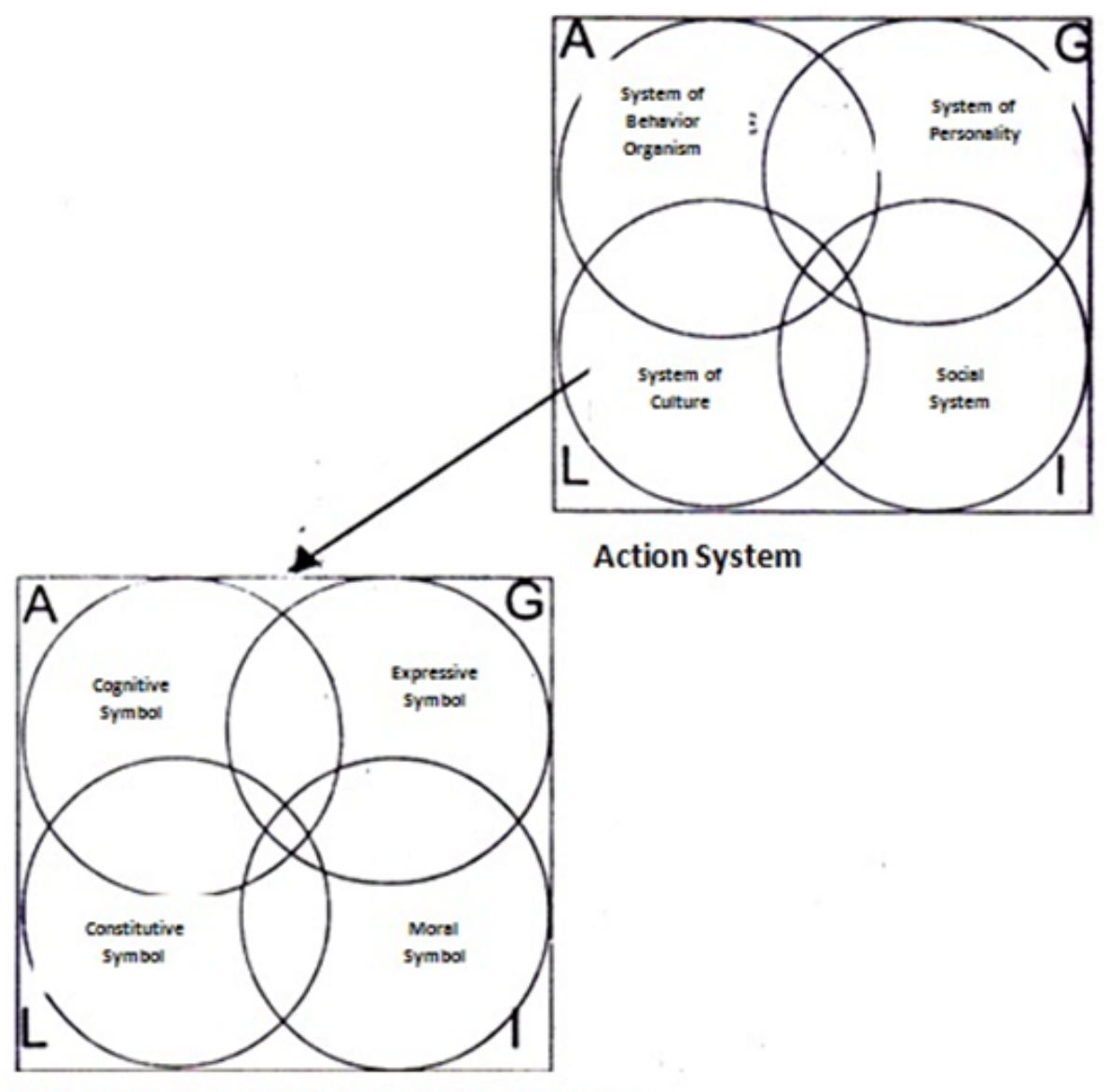

Sub-System of Culture as System of Symbol

FIGURE 1. Cultural as symbol system (Waters, 1994)

Adaptations are performed by humans by adjusting and changing external environments. While goal Attainment function is enabled by the personality system by setting system objectives and mobilizing resources to achieve it. The integration function is done by the social system, and latent is functioning as a cultural system. 


\section{METHODOLOGY}

This study used a qualitative approach. As a qualitative study is an activity or interpretive practices on material or objects as well as trying to interpret or interpret phenomena in view of the meanings given by the community (Denzin \& Lincoln, 2011).

A series of representations on traditional Grebeg Maulud ceremonies at the Kasunanan Palace Surakarta are interpreted from various data obtained through observations, literature studies, interviews and documentation with the society who are the actors in the ritual.

This exploration focuses on a philosophical case study of the Grebeg Maulud ritual that is routinely held in the Kasunanan Palace, Surakarta, Indonesia. More specifically on the material objects that exist in the ritual, such as: gunungan, distinctive colors, processions that produce findings of meaning or representation of culture, religion and its relation to art activities in it.

\section{RESULT AND DISCUSSION}

\section{Ritual Grebeg in Cognitive Symbolization}

Grebeg derived from the Javanese language Garebeg, Grebeg, Grebeg means the sound of a roaring wind. The Javanese noun, Anggarebeg implies the meaning of a king, a magnifying or a bride. Grebeg is a ceremony, the event of the king of the Palace accompanied by sons and the whole retainer of the palace. It can also be interpreted, the king goes by hundreds of people. This ceremony is usually attributed to the great day of Islamic religion (Setiadi, 2000).

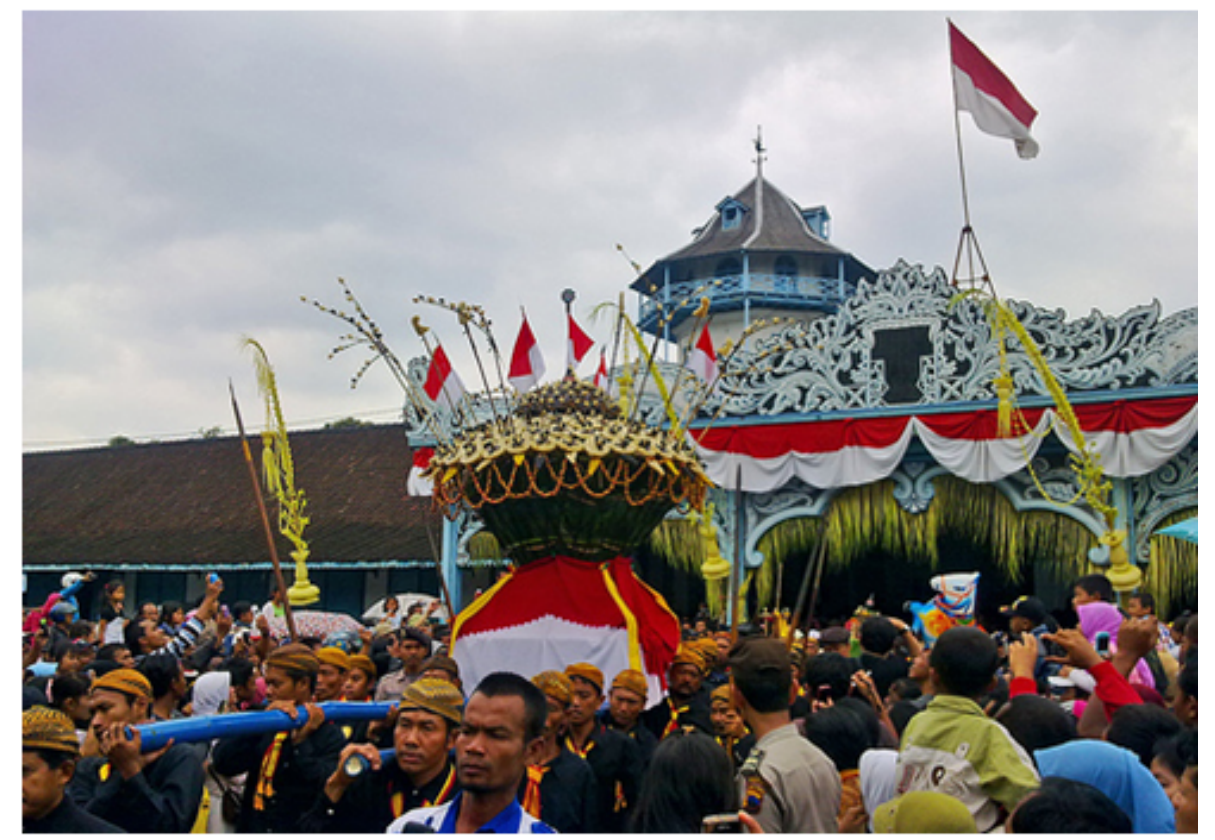

FIGURE 2. Celebration of grebeg maulud at Kasunanan Palace surakarta (Source: Authors)

K.R.H. T Kusuma Tanaya as spiritual advisor of Kasunanan Palace Surakarta said as quoted by Minggu Pagi newsletter of the year 49, No. 20, 1995 page 9 that Grebeg Maulud at Kasunanan Palace Surakarta is a ceremony of Islamic traditions harmonised with the Javanese culture that has thousands of years settlers in the soul of society (Hadi, 2006). Adaptation needs are met through sub-systems cognitive symbols (Cognitive symbolization). Through the process of adaptation, ritual ceremony Grebeg Maulud at Kasunanan Palace Surakarta is a form of ritual accepted by the community and has been implemented continously since Raden Patah was crowned Sultan I Sultanate of Demak as The first Islamic kingdom in Java, which had broken down the Majapahit Empire in 1478 ad or 1400 Saka known as Candrasengkala Sirna lost Kertaning Bumi (Poeger, 2002).

\section{Grebeg Ritual in Expressive Symbolization}

Concrete form of expressive symbol (expressive symbolization) in the goal of attainment in the form of expressive deeds in artwork and other symbolic communication. In the ritual of Grebeg Maulud there are some aesthetic elements that can be categorized as artwork, namely: Gunungan and gamelan accompaniment embodied in gending jawi.

After the celebration of Sekaten lasted for 7 days, right on 12 Rabiulawal, the birthday of the Prophet Muhammad SAW, held a ceremony of celebration with the offerings of Gunungan held by Sinuhun Paku Buwana. The issuance of the Gunungan signifies that the show Grebeg Maulud has entered the top event. Gunungan is the symbol of the king's charity to his people and brings blessings. People believe that the objects in the Gunungan have magical powers. 
The inauguration ceremony began with the abdication, Ingkang Sinuhun ordered Pepatih Dalem to convey the command to Kyai Penghulu Tapsiranom in order to lead the ceremony of Maulud Prophet Muhammad SAW and read the prayer as needed. The traveling troupe of Gunungan is preceded by a dance. This was done by the Brahmana with the intent to test the sincerity of the Pepatih-faith in carrying out the order of Ingkang Sinuhun. If the job is to laugh, it can still be teased.

Gunungan is comprised of Gunungan Lanang (Gunungan male) and Gunungan Wadon (Gunungan female). Gunungan is made of various kinds of traditional food. KGPH Hadiwijaya explained as follows: Gunungan (the origin of the word mountain) consists of 24 Jodang, 12 of the Gunungan of the

mountains of men and 12 female Jodang Gunungan. During there are children (Saradan) and 24 Ancak-Canthaka. The mountain of males in the form of Tumpengan, Lingga or Meru is higher than the height of the standing, he was put in the form of ento-ento (type of food that is rounded-shape) as many as 4 pieces and topped 1 piece. It symbolizes the true taste, the type that we can see on the stone monument of Sukuh Temple (Sukuh, Tawangmangu) which now has a small flag of coconut sugar (red white) is reversed, which also symbolises female male. Gunungan is a body shaped like a gender. Hence it is called a snare. Everything is not different from the Gunungan of males above. between the Gunungan, there are children called Saradan.
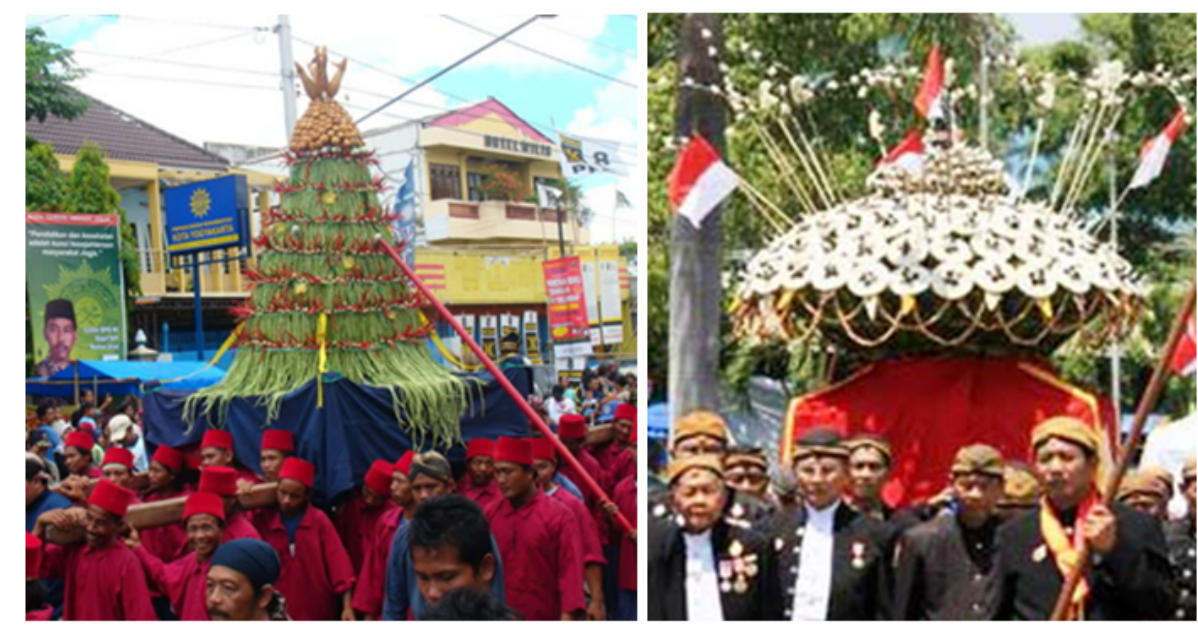

FIGURE 3. Gunungan lanang (left) and gunungan wadon (right) (Source: Authors)

Jodhang used to put the Gunungan is given a decoration that contains its own meaning, and has a symbolic meaning, among others are given a campaign (cover from half the height down) of the fabric beautiful Bangotulak, magnificent and authoritative.

For the daily purpose of the offerings/the usual determination we encounter red white Jenang, the whiteness should be placed on the red. It symbolizes the male-female, as it is contained in the sugar symbol - which is reversed, whiteness above the red below. About the number 24 of AncakCanthoka resembles Kodhok (frog), given a container covered in brass iron.

The Gunungan runs past in front of Ingkang Sinuhun in Sitinggil, through the North Square and on to the Great Mosque. The Gunungan was honored by the Mungga's gending (traditional song). Arriving at the group of AncakCanthoka gending (traditional song) transformed into Kodhok Ngorek.

Furthermore, the number (count) 12-24-2 above each has a sibolis meaning equal to a special count $3=$ trimurti, 4
= keblat, 2 = loro, loroning atunggal, and so on. The western scientific set is called twiddling and multiplication of the figures above if the next $12 \times 2-24$ is the earth's rotation around the sun one day a night for 24 hours.

After the group reached the foyer of the Grand Mosque, Pepatih Dalem told the Hajat Ingkang Sinuhun to Kyai Penghulu Tafsiranom and asked to read the prayers according to the proper. The Prince of Tafsiranom accepted the surrender, leading the way to completion. Then after the ceremony, the Gunungan and the Tumpeng Sewu are distributed to all who attend, not to be missed, sent to Ingkang Sinuhun and the authorities deemed necessary.

\section{Grebeg Ritual is Moral Symbolization}

Gunungan in the tradition of Grebeg Maulud at Kasunanan Palace Surakarta is always consist of Gunungan Lanang (Gunungan male), Gunungan Wadon (Gunungan female) and Saradan (Gunungan Children). The philosophy of the Palace argues that human life comes from the relationship of male and female related in marriage called a family and with the 
resultant son and or daughter (Poeger, 2002).

Man, in his life, since birth is always accompanied by kandang papat (four) lima (five) pancer. Kandang Papat are kawah (crater), getih (blood), tasik and adhi ari-ari (placenta). The location of this kandang papat is in line with the Javanese human qibla direction too. The kawah putih (white crater) is on the east as the opening of the starting road. The red-colored getih (blood) is in the south. The black puser (navel) is in the west and the yellow adhi ariari is in the north. While the pancer is in the middle.

The saradan is surrounded by four black, yellow, red and white colors. It is explained that man since birth is already ruled by lust. Lust means the cradle of, an inner energy that encourages men to pursue worldly pleasures or ukhrawi pleasures. Human lust is actually one, but it is called four kinds:

a. Angry lust means fierce nature, which emphasizes emotion. It is symbolized in red.

b. Lawwamah lust means angangsa, causing thirst, drowsiness and hunger or the selfish nature of eating. It is symbolized by the black color.

c. Sufiyah lust means to be passionate, or a trait that is selfish. It is symbolized in yellow.

d. Muthmainah lust means tranquility, has a character of goodness, virtue and nobility. It is symbolized by the white color.

Good human beings are people who prioritize Mutmainah nature. In order for human life to be safe, can control the bad nature. The moral symbol in the tradition of Grebeg Maulud at Kasunanan Palace Surakarta represents the philosophy and the hakikat (reality) of man as the creature of God's creation.

\section{Grebeg Ritual in the Constitutive}

The implementation of the tradition of Grebeg Maulud at Kasunanan Palace Surakarta especially in Gunungan as symbolic action can be found ontological view of reality namely the origin and purpose of life, the view of natural nature, the view of human nature, views on the nature of God and the relationship of man with God to achieve the perfection of life known as the paraning dumadi-manunggaling kawula-gusti.

The view of Kejawen says that God and the creation are the same, yes different; God is transcendent with a total of the so called Tan Keno Kinoyo Ngopo and in total is called Pamoring Kawula - Gusti. Pamoring Kawula - Gusti, also called Manunggaling Kawula - Gusti or Jumbuhing Kawula - Gusti (Suseno, 200).

The shape of the Gunungan such as Tumpeng (cone) with tapered shoots has meaning as:

a. The symbol of human journey from birth to return to the highest point of the supreme Creator.

b. The emblem of the paraning dumadi.

c. The reference means completely united to the creator.

d. Means of worship to the one true God.

Research from Adib and Gustami (2003) suggests that in the celebration of Grebeg Maulud there is an artistic aspect in the Gunungan Grebeg Maulud. The inclusion of Islamic teachings in Indonesia can be easily accepted by the Javanese community because the Wali (propagators of Islam in Indonesia) convey their da'wah material by including art as a medium for their Islamic preaching (Adib \& Gustami, 2003).

\section{CONCLUSION}

The view on functional in Grebeg Maulud ritual is symbolized in various systems. Discussion of structural functionalism theory of Parsons begins with four important schemes known as AGIL scheme. According to Parsons, there are four essential functions that are absolutely necessary for all social systems, including a system of behavioral organisms fulfilling the customization needs (Adaptation), with the abbreviation $A$, the personality system meets the needs of achievement Objectives (Goal Attainment), abbreviated $\mathrm{G}$, social system is a source of integration (Integration), abbreviated I, and the cultural system maintains the existing patterns (Laten pattern-maintenance), abbreviated $\mathrm{L}$.

There is a correlation between the constituent symbols (religion) and the expressive symbol (art) in religious rituals. The constituent symbols and expressive symbols contain an aesthetic element of religion. The constituent symbols in the Grebeg Maulud ritual are reflected in the Gunungan which contains the philosophy of the nature of God and the relationship of man with God to achieve the perfection of life known as the Paraning Dumadi - Manunggaling Kawula - Gusti. The expressive symbol in the Gunungan symbolizes the male (Gunungan Lanang) and the female (Gunungan Wadon). Gunungan is an aesthetic element in religion containing the constituent symbols and expressive symbols in it.

\section{LIMITATIONS AND RECOMMENDATIONS}

The limitation of this study is the respondents are only limited to the perpetrators of the Grebeg Maulud ceremony. Further research respondents can be developed on local residents, tourists or immigrant in order to obtain more holistic findings.Possible further research from this initial exploration is ethnographic-based research on the perpe- 
trators of traditional ceremonies Grebeg Maulud at Kasunanan Palace Surakarta. The perpetrators consisted of two criteria, first was the executor of the palace who served in the Grebeg Maulud ritual and second was the people in- volved and routinely participated in the ritual procession from the beginning to the end of each year.

\section{REFERENCES}

Adib, A., \& Gustami, S. P. (2003). Makna dan fungsi simbolik gunungan garebeg maulud kraton surakarta (kajian aspek kesenirupaan). Sosiohumanika, 16(5), 56-70.

Adler, R., \& George, R. (2006). Understanding human communication. New York, NY: Oxford University Press.

Berg, B. L. (2001). Qualitative research methods for the social science. New York, NY: Pearson Education Company.

Denzin, N. K., \& Lincoln, Y. S. (2011). Introduction: The discipline and practice of qualitative research. Thousand Oaks, CA: Sage.

Fredy, H. (2009). Mengenal keraton ngayogyakarta hadiningrat. Yogyakarta, Indonesia: Warna Grafika.

Galuh, P. (2019). Jathilan: Between the javanese sacred rituals and performance in tourism attractions. Journal of Advances in Humanities and Social Sciences, 5(5), 207-215. doi:http://dx.doi.org/10.20474/jahss-5.5.2

Hadi, Y. S. (2006). Arts in religious ritual. Yogyakarta, Indonesia: Library Publisher.

Koentjaraningrat, N. (1987). Sejarah teori antropologi $i$. Jakarta, Indonesia: penerbit Universitas Indonesia (UI- Press).

Kuncoro, Y. A. (2018). Komunikasi ritual garebeg di keraton Yogyakarta. Jurnal Aspikom, 3(4), 623-634. doi:http://dx.doi .org/10.24329/aspikom.v3i4.189

Ngwaru, J. M. (2017). Multi-literacies pedagogy design: The case of focused ethnographic research and catalytic validity in literacy development. International Journal of Humanities, Arts and Social Sciences, 3(2), 31-43. doi:https://dx.doi.org/ 10.20469/ijhss.3.20001-2

O'dea, T. F. (1995). The sociology of religion. Prentice-Hall, NJ: The University of Virginia.

Parsons, T. (195). The social system. New York, NY: The free Press.

Poeger, G. P. H. (2002). Sekaten. Surakarta, Indonesia: Karaton Kasunanan.

Purwadi, L. (2003). Sejarah sunan kalijaga. Yogyakarta, Indonesia: Persada.

Ritzer, G. (1996). Modern sociological theory. London, UK: SagePublications.

Saddhono, K. (2009). Tradisi sekaten di keraton kasunanan surakarta. Jurnal Pendidikan dan Kebudayaan, 5(9), 56-70.

Serena, N., \& Richard, L. W. (2007). Cultural anthropology. New york, NY: Thomson.

Setiadi, B. (2000). Keraton kasunanan surakarta and paku buwono xii, king in republic life. Jakarta, Indonesia: PT. Bina Rena Pariwara.

Silva, H. M. S. V., \& Madushani, R. A. I. (2017). The impact of human resource competencies of front line employees on tourist arrivals of unclassified hotels in Western Province, Sri Lanka. Journal of Advanced Research in Social Sciences and Humanities, 2(1), 9-16. doi:https://doi.org/10.26500/jarssh-02-2017-0102

Soepanto, S., \& Bambang, S. (1991). Upacara tradisional sekaten daerah istimewa Yogyakarta. Yogyakarta, Indonesia: Departement $\mathrm{P}$ dan $\mathrm{K}$.

Suseno, F. M. (200). A phylosophical analysis on javanese life wisdom. Yogyakarta, Indonesia: Gramedia Pustaka Utama.

Utami, H. E. (2011). Kidung sekaten antara religi dan ritus sosial budaya. Harmonia: Journal of Arts Research and Education, 11(2), 67-80. doi:https://doi.org/10.15294/harmonia.v11i2.2208

Waters, M. (1994). Modern sociological theory. Thousand Oaks, NJ: SagePublications. 